\title{
Mac 387 antibody and detection of formalin resistant myelomonocytic $\mathrm{L} 1$ antigen
}

\author{
P BRANDTZAEG, ${ }^{*}$ D B JONES,$\dagger$ D J FLAVELL,$\dagger$ M K FAGERHOL $\ddagger$ \\ From the * Laboratory for Immunohistochemistry and Immunopathology (LIIPAT), Institute of Pathology, \\ University of Oslo, The National Hospital, Rikshospitalet, Oslo, Norway, the †University Department of \\ Pathology, Southampton General Hospital, Southampton, and the $\ddagger$ Blood Bank and Department of Immunology, \\ Ullevål Hospital, Oslo, Norway
}

SUMMARY The murine monoclonal antibody Mac 387 was raised against a purified protein fraction obtained from human monocytes. By immunoblotting experiments, Mac 387 was shown to react with a previously defined antigen called $\mathrm{L1}$; this is a multichain myelomoncytic protein of about $36 \mathrm{Kd}$ which shows sequence homology with the cystic fibrosis antigen. The L1 protein is present in the cytoplasm of virtually all resting peripheral neutrophils and monocytes; it is also variably expressed on the plasma membrane of these cells, possibly as a secretory product. Because the Ll antigen is resistant to denaturation by formalin, its tissue distribution can be studied in routinely processed biopsy material. In a wide variety of specimens Mac 387 was shown by immunohistochemical analysis, to produce a cytoplasmic staining pattern concordant with that of a well defined polyclonal antibody to the L1 antigen. Cytoplasmic reactivity was obtained with granulocytes and infiltrating macrophages but generally not with several categories of dendritic cells. In addition, squamous epithelium of mucous membranes was strongly positive, in contrast to normal epidermis.

The human $\mathrm{L} 1$ antigen is a multichain protein of about $36 \mathrm{Kd}$ first isolated from granulocytes; it binds calcium ions avidly and shows a striking heterogeneity on isoelectric focusing.' Like lysozyme and myeloperoxidase, $\mathrm{Ll}$ occurs in both circulating neutrophils and monocytes. ${ }^{2}$ It is of interest that the L1-light chain shows sequence homology with the cystic fibrosis antigen, ${ }^{34}$ and the two $\mathrm{Ll}$ chains seem to be identical with the recently described macrophage migration inhibitory factor (MIF)-related proteins MRP-8 and MRP-14. ${ }^{35}$

The $\mathrm{Ll}$ antigen is remarkably well preserved in formalin fixed and paraffin wax embedded routine biopsy material. ${ }^{6} \mathrm{Ll}$ shows a restricted distribution within the monocyte-derived cell lineage, being mainly confined to reactive histiocytes (infiltrating macrophages). It is usually lacking in HLA-DR positive interdigitating cells, Langerhans' cells, intestinal histiocytes, Kupffer cells of normal livers, and follicular dendritic cells. ${ }^{6}$ A protein sharing physicochemical and antigenic properties with $\mathrm{Ll}$ has been identified in psoriatic epidermal extracts. ${ }^{7}$ It is generally not expressed by normal epidermis but is abundant in several inflammatory skin diseases ${ }^{8}$ and adjacent to

Accepted for publication 7 April 1988 various skin tumours. ${ }^{9}$ Moreover, mucosal squamous epithelium normally expresses $\mathrm{L} 1{ }^{7}$

A rabbit antiserum S22, raised against human monocytes showed some similarities to anti- $\mathrm{Ll}$ when tested by immunohistochemical techniques. ${ }^{10}$ The $\mathbf{2 2} 2-$ related antigens, however, were found to be expressed by Kupffer cells in normal livers and also by interdigitating cells. A similarly prepared antiserum S42 was recently used to capture detergent-solubilised monocyte proteins which were then used to raise a murine monoclonal antibody." This study aimed to show that Mac 387 is specific for the well defined L1 antigen.

\section{Material and methods}

A variety of biopsy specimens were obtained from the routine pathology files. ${ }^{6}$ This material had been fixed in buffered formalin ( $\mathrm{pH} 7.4$ ) and embedded in paraffin wax. A similar selection of tissue was obtained as fresh material and prepared by direct ethanol fixation at $4^{\circ} \mathrm{C}$ followed by paraffin wax embedding according to the method of Sainte-Marie. ${ }^{12}$

PRIMARY ANTIBODY REAGENTS FOR

IMMUNOHISTOCHEMISTRY

Production and characterisation of monoclonal Mac 
387 have been detailed elsewhere. " Fluorescein and rhodamine conjugates were prepared from appropriately absorbed antisera with various specificities, including anti- $\mathrm{L} 1 .^{21314} \mathrm{~A}$ rabbit antiserum to S-100 protein (A588, Dako, USA) was used to label Langerhans' and interdigitating cells. ${ }^{15}$ All antibody incubations took place at room temperature for $\mathbf{3 0}$ minutes or $\mathbf{2 0}$ hours; the reagents were appropriately diluted in isotonic phosphate buffered saline (PBS), $\mathrm{pH} 7 \cdot 5$, containing bovine serum albumin (BSA) at $125 \mathrm{~g} / \mathrm{l}$.

\section{IMMUNOENZYME STAINING}

Sections (4-6 $\mu \mathrm{m})$ of formalin fixed tissues were stained with or without trypsin $(1.0 \mathrm{~g} / \mathrm{l})$ pretreatment for $10-15$ minutes at $37^{\circ} \mathrm{C}$. Antigen localisation was achieved by the alkaline phosphatase anti-alkaline phosphatase (APAAP) method, ${ }^{16}$ as detailed previously. ${ }^{6}$ Mac 387 was applied as ascitic fluid at dilutions of $1 / 1200$ to $1 / 2400$ for 20 hours on formalin fixed sections. The latter condition could likewise be used on ethanol fixed sections, but incubation for 30 minutes at $1 / 400$ was preferable to avoid leaching out of cytoplasmic $\mathrm{L} 1$ antigen. Antiserum to $S-100$ protein was applied on formalin fixed sections at $1 / 1500$ for 20 hours. After the final wash all sections were counterstained with haematoxylin.

PAIRED IMMUNOFLUORESCENCE STAINING

A rhodamine labelled rabbit IgG $(0 \cdot 18 \mathrm{~g} / \mathrm{l})$ anti-L1 conjugate was applied on ethanol fixed tissue sections for $\mathbf{3 0}$ minutes and on formalin fixed sections for $\mathbf{2 0}$ hours. Mac 387 was used at 1/800, either mixed with the rhodamine conjugate or applied first in sequential incubations. Its reaction sites were finally shown by a two step method using biotinylated horse anti-mouse IgG and fluorescein labelled avidin. ${ }^{13}$ The red signal of the anti- $\mathrm{L} 1$ conjugate was enhanced by inclusion of rhodamine labelled swine anti-rabbit IgG in the last incubation step. ${ }^{13}$ The same detection system was used for paired staining with antiserum to $S-100$ protein (1/ 300) and Mac 387. The sections were evaluated in a Leitz Orthoplan microscope with a Ploem-type epiilluminator.

\section{IMMUNOBLOTTING EXPERIMENTS}

L1 protein was purified from a crude leucocyte extract by preparative isoelectric focusing. ' For analytical focusing, $\mathrm{L} 1$ samples ( $\sim 50 \mu \mathrm{g}$ in $15 \mu \mathrm{l}$ water) were applied near the cathode of agarose gels containing $7.5 \%$ proprietary (LKB, Sweden), $\mathrm{pH} 5$ to $\mathrm{pH} 8$. The protein bands were transferred ${ }^{17}$ to a nitrocellulose sheet (Bio-Rad, USA), which was subsequently cut into two equal parts. These were soaked in appropriately diluted polyclonal or monoclonal antibody reagents (such as Mac 387 at 1/400) for three hours at room temperature. Thereafter incubation took place overnight with peroxidase-labelled goat anti-rabbit or anti-mouse IgG conjugate at 1/1000 (Bio-Rad). The enzyme substrate was diaminobenzidine in $0.1 \mathrm{M}$ sodium citrate, $\mathrm{pH} 5$, with $0.015 \%$ $\mathrm{H}_{2} \mathrm{O}_{2}$.

Dot blot experiments were performed with crude leucocyte extract containing a known amount of $\mathrm{Ll}$ antigen and with two fractions of purified $\mathrm{L} 1$ protein. ${ }^{1}$ After application of the samples $(1 \mu \mathrm{l})$ in two-fold serial dilutions (representing from 2000 to $0.2 \mathrm{ng} \mathrm{L1}$ antigen), the nitrocellulose sheets were soaked in buffer containing BSA (30 g/l) overnight and were therafter stained with the APAAP method using polyclonal anti-Ll or monoclonal Mac 387 applied as described above for ethanol-fixed tissue sections. Colostral IgA (2000 ng) was applied as a control protein sample, and monoclonal anti-IgA2 was used as a control murine antibody at a dilution comparable with that of Mac 387.

\section{Results}

\section{IMMUNOHISTOCHEMISTRY}

Mac 387 and polyclonal anti-Ll applied in the APAAP method produced virtually identical staining results, but Mac 387 required more appropriate trypsinisation of formalin fixed sections. In such sections more extracellular L1 was shown by the polyclonal reagent, probably because protein antigens are particularly masked in the interstitial matrix by cross linking fixatives. ${ }^{18}$

Both antibody reagents produced remarkably distinct staining of infiltrating macrophages (fig 1). Epithelioid cells were variably positive; macrophage giant cells were negative or only faintly stained. Various dendritic cells were generally negative as described previously. ${ }^{6}$ One exception was a minor population of putative interdigitating dendritic cells in some $T$ cell areas of lymph nodes and tonsils; paired staining with Mac 387 and antiserum to $S-100$ protein showed a variable cell fraction with concomitant cytoplasmic staining (fig 2). This fraction could be somewhat increased in dermatopathic lymphadenopathy. ${ }^{19}$

Mac 387 and polyclonal anti-Ll both stained normal oral, pharyngeal, and vaginal squamous epithelium in a similar pattern; normal epidermis was negative except the pilosebaceous units. ${ }^{6}$

\section{COMPARATIVE TWO-COLOUR STAINING}

Sequential paired immunofluorescence, with Mac 387 applied before the polyclonal anti- $\mathrm{L} 1$, produced in all cases concordant staining features. Concomitant green and red cytoplasmic fluorescence was seen in granulocytes and histiocytes of reactive lymph nodes, 

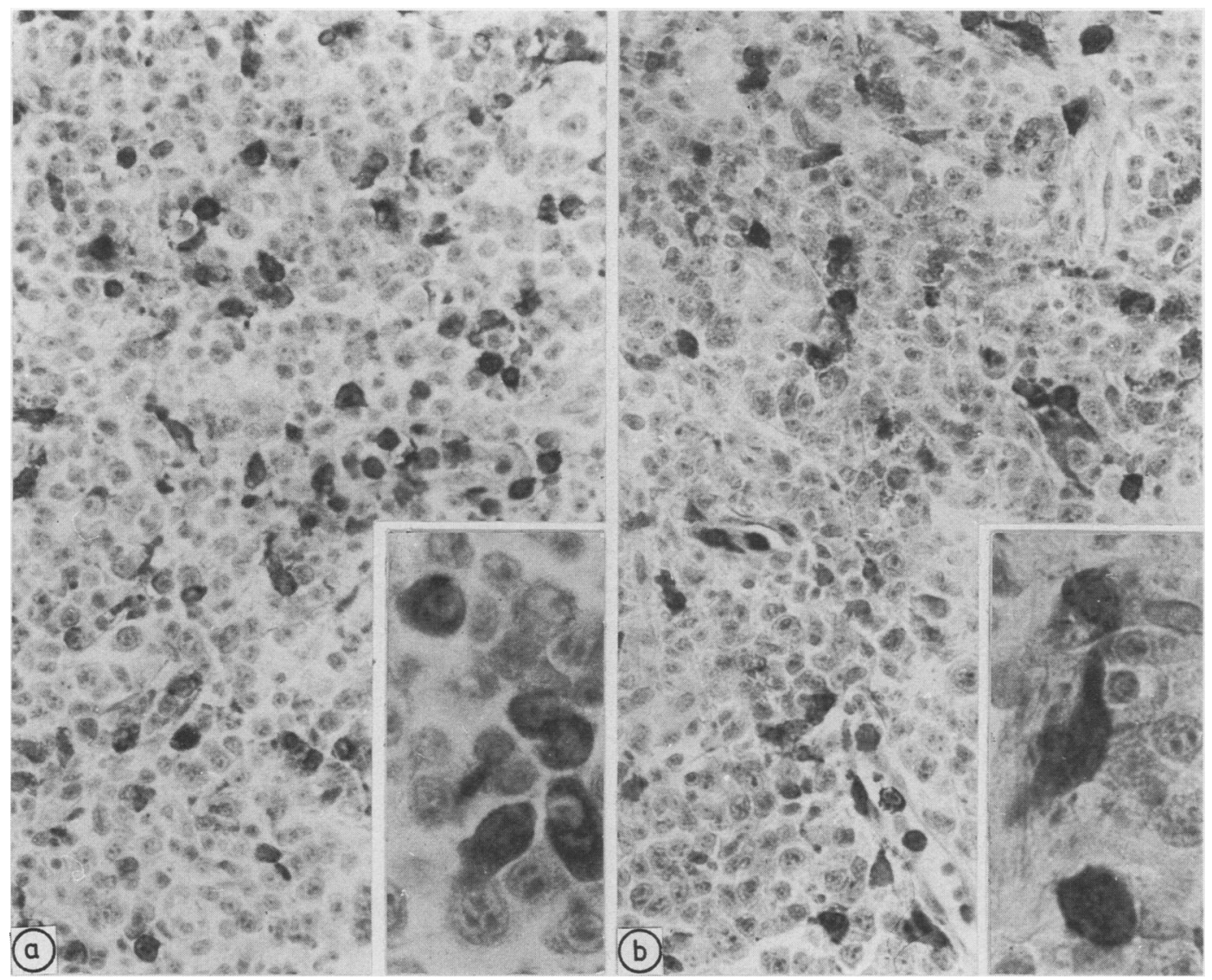

Fig 1 L1-positive macrophages in adjacent sections of ethanol-fixed specimen from tonsillar non-Hodgkin's large cell lymphoma. APAAP labelling counterstained with haematoxylin. (a) Primary reagent was polyclonal antiserum to LI antigen (b) primary reagent was monoclonal Mac 387.

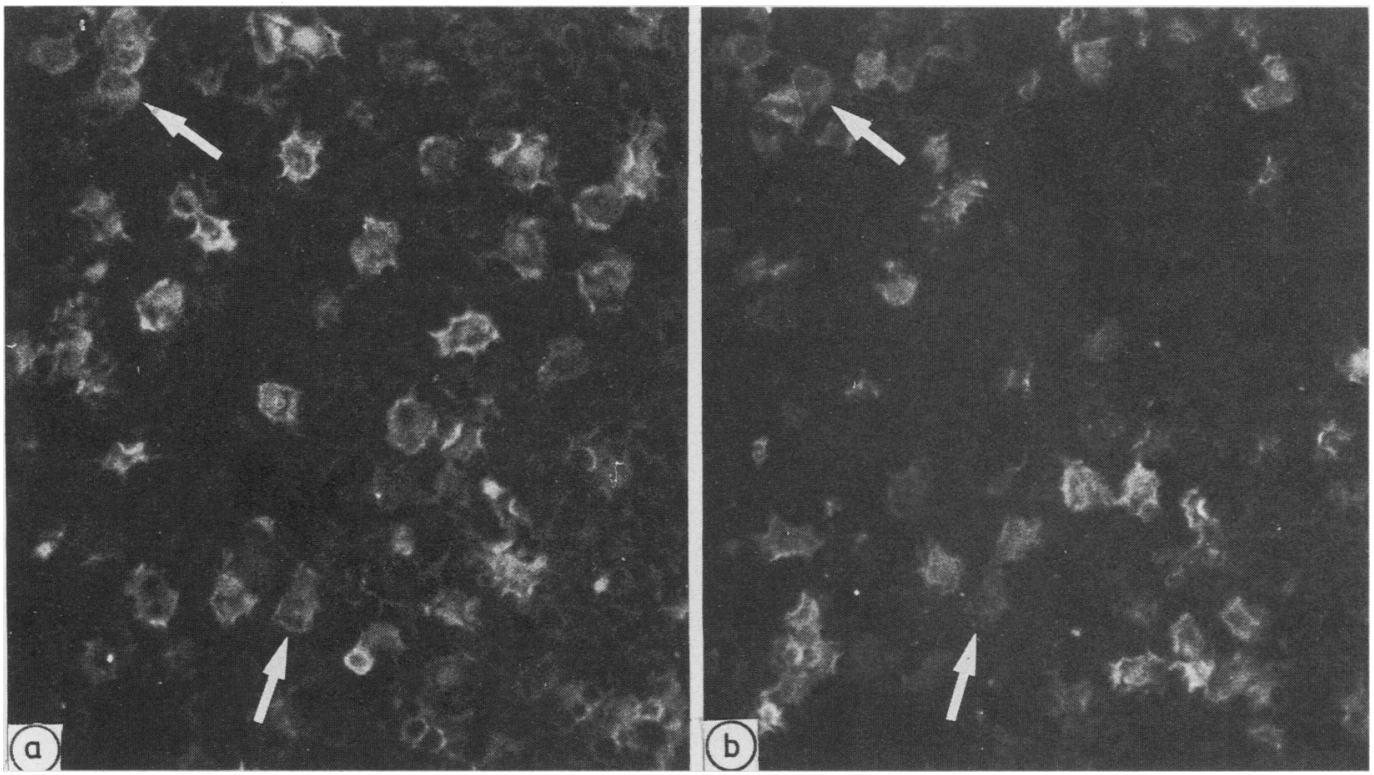

Fig 2 Concurrent paired immunofluorescence staining of histiocytes in paracortical field from trypsinised section of formalin fixed reactive lymph node. Left panel: rhodamine labelling with antiserum to S-100 protein; right panel, fluorescein labelling with Mac 387. There are numerous $S-100$ protein-positive, presumably interdigitating dendritic cells (left), but also many cells of similar appearance detail labelled by Mac 387 (right); only few cells (arrowed) show concomitant labelling. 


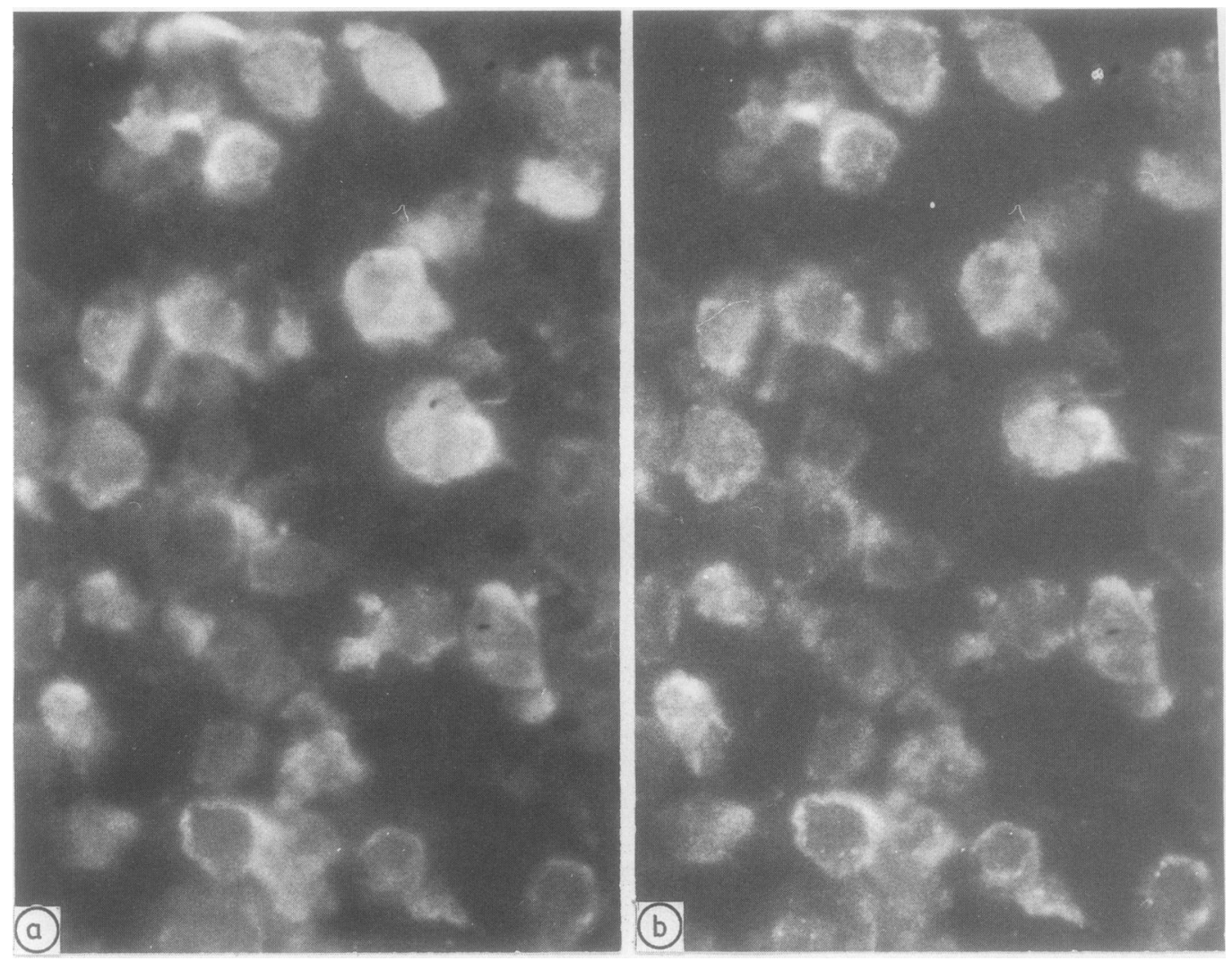

Fig 3 Sequential paired immunofluorescence staining with anti-serum to L1 antigen (left panel, rhodamine) and Mac 387 (right panel, fluorescein) in field from a trypsinised section of formalin fixed specimen from a true histiocytic malignant lymphoma. All neoplastic cells show concomitant labelling.

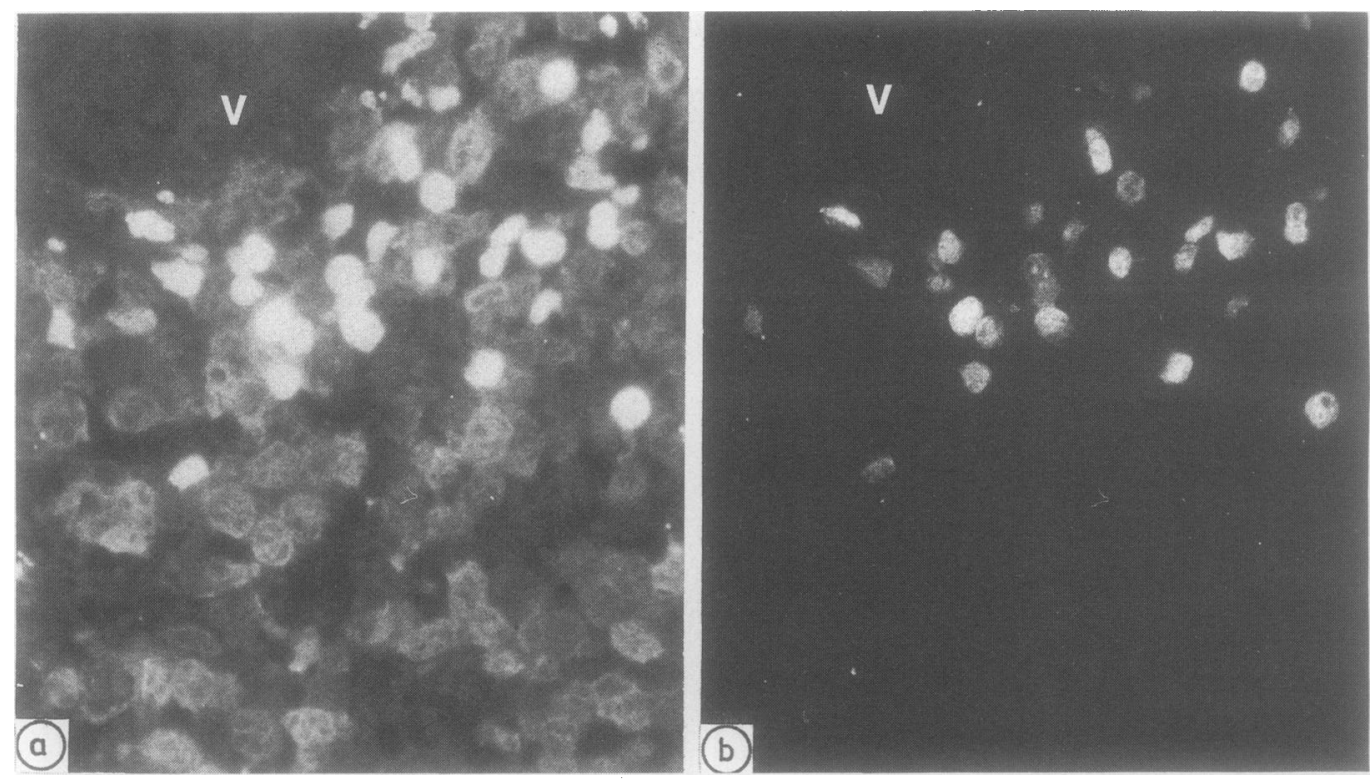

Fig 4 Concurrent paired immunofluorescence staining with antiserum to LI antigen (left panel, rhodamine) and Mac 387 (right panel, fluorescein) in field from a trypsinised section of formalin fixed specimen from a true histiocytic malignant lymphoma. Neoplastic cells show selective faint red staining, whereas granulocytes adjacent to vessel ( $V$ ) show concomitant labelling. 


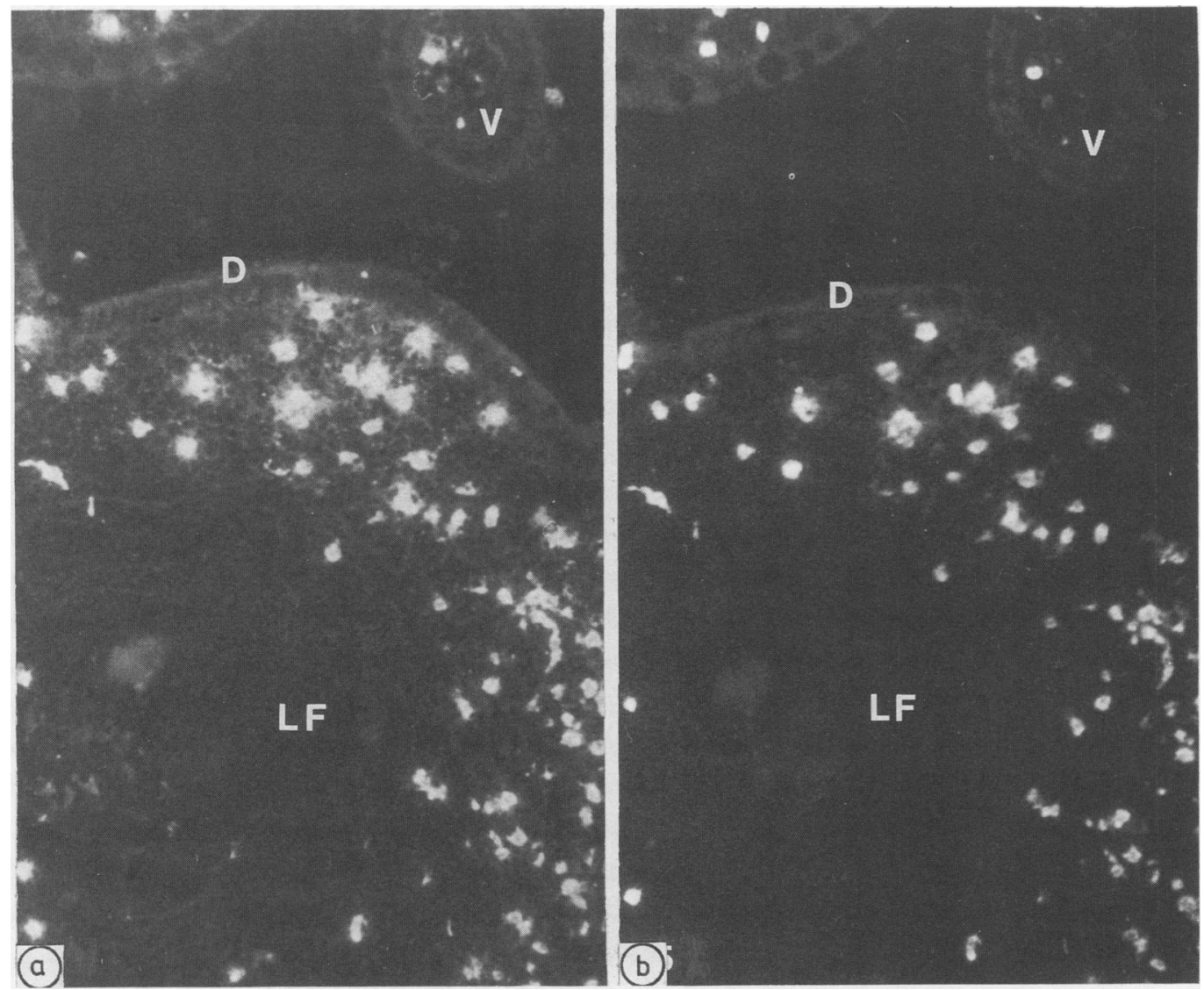

Fig 5 Concurrent paired immunofluorescence staining with antiserum to L1 antigen (left panel, rhodamine) and Mac 387 (right panel, fluorescein) in a section of ethanol fixed specimen from ileal mucosa. All macrophages in Peyer's patch show concomitant labelling. $V=$ villus epithelium; $D=$ dome epithelium; $L F=$ lymphoid follicle.

tonsils, and mucous membranes, and also in mucosal squamous epithelia. Two Ll positive histiocytic malignant lymphomas were likewise identically stained by the two reagents after sequential incubation (fig 3).

Conversely, when the two antibody reagents were mixed, concomitant fluorescence was mainly obtained where the Ll antigen was present in high concentrations, such as in granulocytes (fig 4) and squamous epithelia. With this approach Mac 387 failed to decorate weakly Ll-positive subpopulations of normal or malignant (fig 4) histiocytes and extracellular L1 antigen; the polyclonal reagent presumably had a greater avidity for $\mathbf{L} 1$ and therefore partially blocked the reactivity of Mac 387.

Competitive inhibition of Mac 387 was not observed, however, when the mixed primary antibody reagents were applied on ethanol fixed sections, probably because the epitope detected by the monoclonal antibody was better preserved by this fixative. Thus in such material there was always complete concordance between the two colours emitted by histiocytes subjected to paired staining (fig 5).

\section{ABSORPTION WITH LI ANTIGEN}

When Mac 387 was absorbed with highly purified Ll antigen $(0.1 \mathrm{~g} / \mathrm{l})$, the staining reaction was abolished for both leucocytes and epithelium. This held true both with formalin and ethanol fixed tonsillar sections. Only occasional granulocytes and epithelial cells with a high $\mathrm{L} 1$ concentration showed faint staining after application of absorbed Mac 387.

\section{IMMUNOBLOTTING RESULTS}

Mac 387 and polyclonal anti-L1 produced identical reaction patterns when compared in Western blots with purified Ll protein separated into various molecular species by isoelectric focusing (fig 6). In dot blots the polyclonal reagent produced a visible 


\section{Mono Mac Ab Poly Anti-L1}

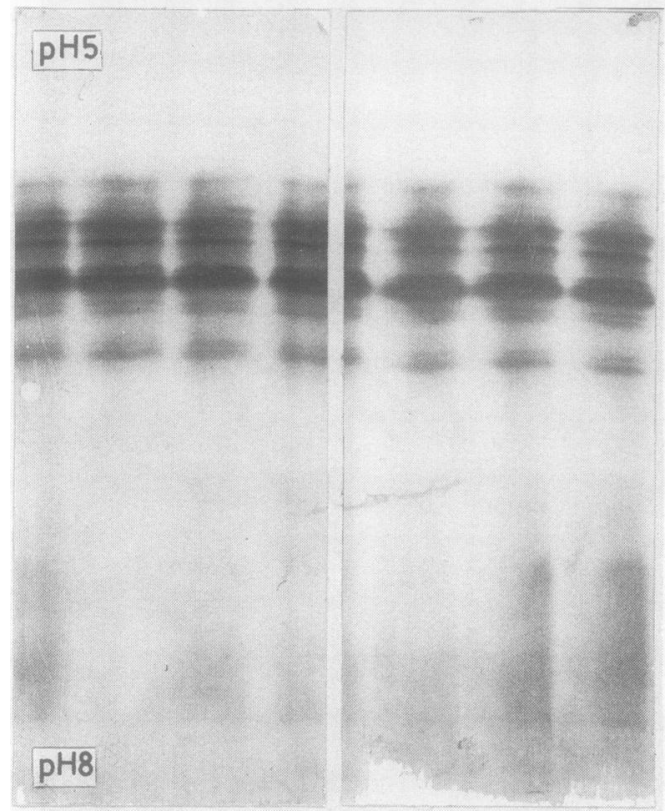

Fig 6 Comparison of molecular patterns shown by Western blotting with Mac 387 (mono mac ab) or polyclonal antibody to L1 antigen (poly anti-L1). Purified LI protein was subjected to isoelectric focusing in agarose gel on a pH 5 to pH 8 gradient, and the protein bands were transferred to a nitrocellulose sheet that was cut into two halves (left and right panel) before antibody incubation.

precipitate with crude leucocyte extract down to an $\mathrm{L} 1$ concentration of about $2 \mathrm{ng}$; the dots produced by Mac 387 were somewhat weaker and had an end point of about $8 \mathrm{ng}$. Parallel results were obtained with the two purified L1 fractions (fig 7). Such dots were not produced in the control sheets with colostral IgA or anti-IgA2. Altogether, the immunoblotting results excluded the possibility that Mac 387 reacted with an epitope that was unassociated with the L1 antigen.

\section{Discussion}

This study showed that the monocyte antibody Mac 387 reacts with the well defined human myelomonocytic $\mathrm{L} 1$ antigen. Our conclusion is based on physicochemical and immunohistochemical tests. It remains to be explained why the molecular weights reported for components detected by Mac 387 in detergent solubilised material obtained from granulocytes and monocytes" were somewhat inconsistent with those previously reported for $\mathrm{L} 1 .{ }^{15}$ One possibility is that the Mac 387 antigens to some extent might have been

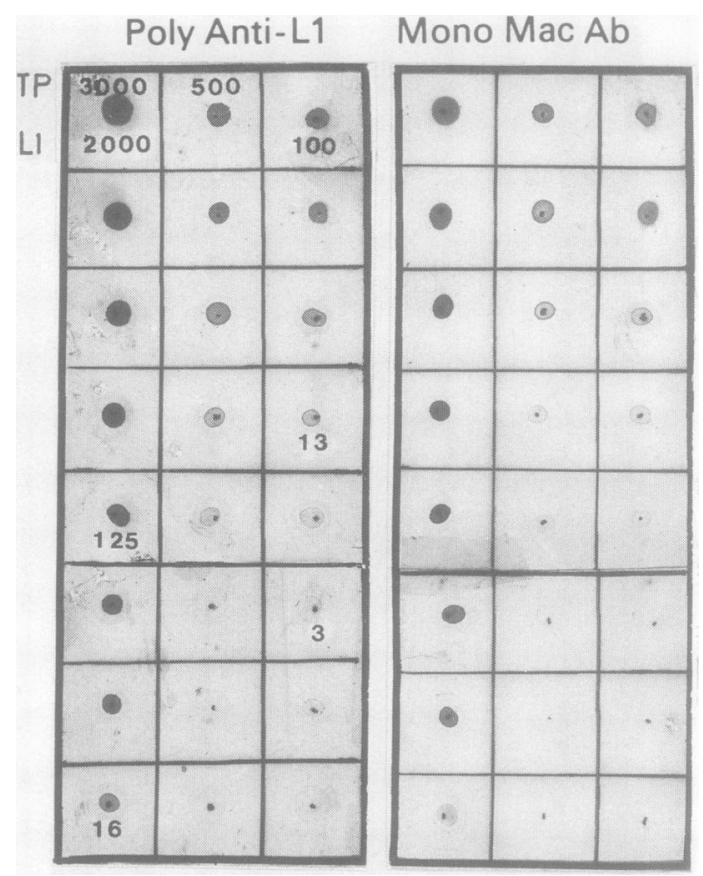

Fig 7 Dot blots obtained by testing polyclonal antibody to L1 antigen (poly anti-L1) or Mac 387 (mono mac ab) against two-fold dilutions (from top to bottom) of crude leucocyte extract (left lane in each panel) and two fractions of purified L1 antigen (middle and right lanes). TP indicates total amount of applied protein and $L 1$ indicates amount of specific antigen as determined by radioimmunoassay. Identical samples were applied in left and right panels, and the numbers show examples of the amounts of TP or $L 1$ antigen in nanograms.

transmembrane $\mathrm{Ll}$ precursors released by the detergent. Moreover, without adequate enzyme inhibition, proteolysis readily takes place in leucocyte extracts. Another possibility is that $\mathrm{Ll}$ behaves differently according to the available concentration of calcium for which it has a remarkable affinity ${ }^{15}$; calcium may thus cause aggregation of $\mathrm{Ll}$ and its binding to other proteins. Such artefacts may not be equally expressed for detergent extracts of granulocytes and monocytes.

The specificity of Mac 387 for the well characterised L1 antigen ${ }^{135}$ renders this antibody a unique immunological reagent which is now commercially available (Dakopatts). Previous monoclonal antibodies to myelomonocytic markers have been raised against surface antigens and have been mainly defined by staining of cell suspensions. When further characterised by immunohistochemistry, these antibodies have performed satisfactorily only on cryostat sections. Moreover, they have shown striking and unexpected specificity heterogeneity, producing 
virtually every possible combination of additional positive staining: $\mathrm{T}$ and $\mathrm{B}$ lymphocytes, ${ }^{2021}$ natural killer cells, ${ }^{22}$ null cells, ${ }^{21}{ }^{23}$ platelets, ${ }^{23}{ }^{24}$ and a variety of dendritic cells. ${ }^{25-27}$ This is in contrast to the restricted leucocyte distribution of the $\mathrm{Ll}$ antigen. ${ }^{26}$ The monoclonal antibody 27E10 apparently showed reactivity with tissue macrophages and squamous epithelium similarly to Mac 387, but it was reported to detect a 17 kD protein and was rarely seen in granulocytes of inflammatory lesions ${ }^{28}$ Conversely, A1-3 seemed to react with tissue granulocytes and macrophages similarly to Mac 387 , but it was reported to detect a 52 $\mathrm{kD}$ protein and cross reacted with some fibroblasts and secretory epithelia. ${ }^{29}$

Unexpected cross reactions-for example, with fibroblasts, endothelium, epithelium, and melanoma cells-have, in fact, been observed by several authors who have tested monoclonal antibodies to myelomonocytic antigens by immunohistochemistry. ${ }^{228-35}$ Such results, however, might be due to common or partially identical epitopes on different molecules. ${ }^{36}$ To our knowledge $\mathrm{L} 1$ is the first protein in addition to HLA molecules and interleukin $1,{ }^{37}$ directly shown to be expressed by both squamous epithelium and leucocytes. ${ }^{7}$ The epithelial reactivity of Mac 387 therefore has a defined molecular explanation. Because of the apparent structural identity of the cystic fibrosis antigen ${ }^{4}$ with the L1 protein, ${ }^{3}$ epithelial reactivity for the former ${ }^{4}$ likewise reflects true antigen expression by keratinocytes.

As L1 is a formalin resistant marker of both macrophages and squamous epithelium, Mac 387 may have several immunohistochemical applications on routine pathological material. (a) $\mathrm{L} 1$ is excellent for labelling of infiltrating histiocytes in malignant lymphomas, thereby identifying cells that may confuse the morphological interpretation by mimicking the neoplastic population. ${ }^{611}(b)$ By paired staining for $\mathrm{L} 1$ and S-100 protein ${ }^{19}$ or HLA-DR, ${ }^{6}$ the proportion of two types of reactive histiocytes can be determined; there are some data to indicate that such information is of prognostic value in relation to certain neoplasms. ${ }^{38-40}$ (c) $\mathrm{Ll}$ is a useful marker of some truly histiocytic tumours (figs 3-4) it has been difficult to identify all such malignancies by previously available phenotypic characteristics. ${ }^{104142}(d) \mathrm{Ll}$ is an interesting epidermal marker in a variety of inflammatory skin diseases ${ }^{8}$ and skin tumours. ${ }^{9}(e) \mathrm{L} 1$ is a promising marker for distinction between squamous cell carcinoma and other carcinomas of the lung. ${ }^{43}$ The availability of a monoclonal antibody to $\mathrm{Ll}$ will hopefully facilitate further immunohistochemical studies of this interesting cell marker protein.

This work was supported by grants from the Norwegian Cancer Society, The Norwegian Society for
Fighting Cancer, the Norwegian Research Council for Science and the Humanities, and the Anders Jahre Fund.

\section{References}

1 Dale I, Fagerhol MK, Naesgaard I. Purification and partial characterization of a highly immunogenic human leukocyte protein, the Ll antigen. Eur J Biochem 1983;134:1-6.

2 Dale I, Brandtzaeg P, Fagerhol MK, Scott H. Distribution of a new myelomonocytic antigen (L1) in human peripheral blood leukocytes. Immunofluorescence and immunoperoxidase staining features in comparison with lysozyme and lactoferrin. $\mathrm{Am} \mathrm{J}$ Clin Pathol 1985;84:24-34.

3 Anderson KB, Sletten K, Berntzen HB, et al. Leukocyte L1 protein: and cystic fibrosis. Nature 1988;332:688.

4 Dorin JR, Novak M, Hill RE, Brock DJH, Secher DS, van Heyningen V. A clue to the basic defect in cystic fibrosis from cloning the CF antigen gene. Nature 987;326:614-17.

5 Odink K, Cerletti N, Brüggen J, et al. Two calcium-binding proteins in infiltrate macrophages of rheumatoid arthritis. Nature 1987;330:80-2.

6 Brandtzaeg P, Dale I, Fagerhol MK. Distribution of a formalinresistant myelomonocytic antigen (L1) in human tissues. 1. Comparison with other leukocyte markers by paired immunofluorescence and immunoenzyme staining. Am J Clin Pathol 1987;87:681-99.

7 Brandizaeg P, Dale I, Fagerhol MK. Distribution of a formalinresistant myelomonocytic antigen (L1) in human tissues. 2. Normal and aberrant occurrence in various epithelia. Am J Clin Pathol 1987;87:700-7.

8 Gabrielsen T- $\varnothing$, Dale I, Brandtzaeg P, et al. Epidermal and dermal distribution of a myelomonocytic antigen (L1) shared by epithelial cells in various inflammatory skin diseases. J Am Acad Dermatol 1986;15:173-9.

9 Gabrielsen T- $\varnothing$, Brandtzaeg P, Hoel PS, Dale I. Epithelial distribution of a myelomonocytic antigen (L1) in relation to cutaneous malignancies and melanocytic naevi. Br J Dermatol 1988;118:59-67.

10 Isaacson PG, Jones DB. Immunohistochemical differentiation between histiocytic and lymphoid neoplasms. Histochem $J$ 1983;15:621-35.

11 Flavell DJ, Jones DB, Wright DH. Identification of tissue histiocytes on paraffin sections by a new monoclonal antibody. $J$ Histochem Cyochem 1987;35:1217-26.

12 Sainte-Marie G. A paraffin-embedding technique for studies employing immunofluorescence. $J$ Histochem Cytochem 1962;10:250-6.

13 Brandtzaeg P, Rognum TO. Evaluation of tissue preparation methods and paired immunofluorescence staining for immunocytochemistry of lymphomas. Histochem $J$ 1983;15:655-89.

14 Brandtzaeg P. Prolonged incubation time in immunohistochemistry: effects on fluorescence staining of immunoglobulins and epithelial components in ethanol- and formaldehyde-fixed paraffin-embedded tissues. $J$ Histochem Cytochem 1981;29:1302-15.

15 Takahashi K, Isobe T, Ohtsuki Y, Sonobe H, Takeda I, Akagi T Immunohistochemical localisation and distribution of S-100 proteins in the human lymphoreticular system. Am J Pathol 1984;116:497-503.

16 Mason DY. Immunohistochemical labelling of monoclonal antibodies by the APAAP immunoalkaline phosphate technique. In: Bullock GR, Petrusz P, eds. Immunocytochemistry vol 3. London: Academic Press, 1985:25-42.

17 Norden AGW, Fulcher LM, Heys AD. Rapid typing of serum paraproteins by immunoblotting without antigen-excess artifacts. Clin Chem 1987;33:1433-6. 
18 Brandtzaeg P, Rognum TO. Evaluation of nine different fixatives. 1. Preservation of immunoglobulin isotypes, $J$ chain, and secretory component in human tissues. Pathol Res Pract 1984;179:250-66.

19 Brandtzaeg P. Immunohistochemical identification of macrophages and various dendritic cells in paraffin-embedded biopsy material. Acta Pathol Microbiol Immunol Scand 1988;(in press).

20 Hanjan SNS, Kearney JF, Cooper MD. A monoclonal antibody (MMA) that identifies a differentiation antigen on human myelomonocytic cells. Clin Immunol Immunopathol 1982;23:172-88.

21 Hirsch S, Gordon S. The use and limitation of monoclonal antibodies against mononuclear phagocytes. Immunobiol 1982;161:298-307.

22 Ho M-K, Springer TA. Preparation and use of monoclonal antimacrophage antibodies. Methods Enzymol 1984;108:313-24.

23 Talle MA, Rao PE, Westberg E, et al: Patterns of antigenic expression on human monocytes as defined by monoclonal antibodies. Cell Immunol 1983;78:83-99.

24 Foon KA, Billing RJ, Fitchen JH, Belzer M, Drew SI, Terasaki PI. An antigen expressed by cells of the myelo-monocytic lineage. Am J Hematol 1981;10:259-67.

25 Franklin WA, Mason DY, Pulford K, et al. Immunohistochemical analysis of human mononuclear phagocytes and dendritic cells by using monoclonal antibodies. Lab Invest 1986;54:322-35.

26 Hogg N, Selvendran Y. An anti-human monocyte/macrophage monoclonal antibody, reacting most strongly with macrophages in lymphoid tissue. Cell Immunol 1985;92:247-53.

27 Seymour GJ, Poulter LW, Bofill M, et al. The reactivity of a monoclonal antibody against cells of the monocytemacrophage series in sections of normal and inflamed human tissues. J Reticuloendothel Soc 1983;34:463-73.

28 Zwadlo G, Schlegel R, Sorg C. A monoclonal antibody to a subset of human monocytes found only in the peripheral blood and inflammatory tissues. $J$ Immunol 1986;137:512-18.

29 Hancock WW, Rickles FR, Ewan VA, Atkins RC. Immunohistological studies with A1-3, a monoclonal antibody to activated human monocytes and macrophages. J Immunol 1986;136:2416-20.

30 Flotte TJ, Springer TA, Thorbecke GJ. Dendritic cell and macrophage staining by monoclonal antibodies in tissue sections and epidermal sheets. Am J Pathol 1983;111:112-24.

31 Hancock WW, Zola H, Atkins RC. Antigenic heterogeneity of human mononuclear phagocytes: immunohistologic analysis using monoclonal antibodies. Blood 1983;62:1271-9.

32 Hogg N, MacDonald S, Slusarenk M, Beverly PCL. Monoclonal antibodies specific for human monocytes, granulocytes and endothelium. Immunology 1984;53:753-67.

33 Howie AJ, Brown G, Fisher AG, Khan M. Wide-spread distribution in human tissue of an antigenic determinant of granulocytes. J Clin Pathol 1984;37:555-9.

34 Zwadlo G, Bröcker E-B, von Bassewitz D-B, Feige U, Sorg C. A monoclonal antibody to a differentiation antigen present on mature human macrophages and absent from monocytes. J Immunol 1985;134:1487-92.

35 Sewell HF, Jaffray B, Thompson WD. Reaction of monoclonal anti Leu M 1 - a myelomonocytic marker (CD15) - with normal and neoplastic epithelia. J Pathol 1987;151:279-84.

36 Gosh S, Campbell AM. Multispecific monoclonal antibodies. Immunol Today 1986;7:217-22.

37 Kupper TS, Ballard DW, Chua AO, et al. Human keratinocytes contain mRNA indistinguishable from monocyte interleukin $1 \alpha$ and $\beta$ mRNA. Keratinocyte epidermal cell-derived thymocyteactivating factor is identical to interleukin 1. J Exp Med 1986;164:2095-100.

38 Nomori H, Watanabe S, Nakajima T, Shimosato Y, Kameya T. Histiocytes in nasopharyngeal carcinoma in relation to prognosis. Cancer 1986;57:100-5.

39 Ree HJ, Crowley JP, Lenone LA. Macrophage-histiocytes in malignant lymphoma, small lymphocytic type (well-differentiated lymphocytic lymphoma). Cancer 1985;56:1117-23.

40 Sangster G, Crocker J, Jenkins R, Leyland MJ. Cells which contain S-100 protein in Hodgkin's disease: a quantitative study. J Clin Pathol 1985;38:1021-4.

41 Isaacson PG. Histiocytic malignancy. Histopathology 1985;9:1007-11.

42 Roholl PJM, Kleyne J, Pijpers HW, van Unnik JAM. Comparative immunohistochemical investigation of markers for malignant histiocytosis. Hum Pathol 1985;16:763-71.

43 Dale I, Brandtzaeg P. Expression of the epithelial L1 antigen as an immunohistochemical marker of squamous cell carcinoma of the lung. Histopathology (in press).

Requests for reprints to: Prof P Brandtzaeg, LIIPAT, Rikshospitalet, N-0027 Oslo 1, Norway. 
Problem Solving in Immunohematology. 3rd ed. Herbert Silver. (Pp 123; \$30.) Raven Press. 1988. ISBN $089189263 \mathrm{X}$.

This excellent short book has an entertaining way of presenting a wide range of problems in blood banking. Its chapters cover processing of donor blood, tests on prospective recipients, antibody identification, blood component inventories, transfusion reactions, prenatal and neonatal testing, $\mathbf{R h}$ immunoglobulin, diagnosis of HDN, and selection of blood for exchange transfusion. The only omission seems to be autoimmune haemolysis. Each section provides a surprising amount of information: a short introduction is followed by a series of exercises aimed to cover the major problems likely to arise in that area. The reader is invited to solve the problems before turning to the authors' answers and interpretations. The book is intended to develop a methodical approach to blood bank problems. It succeeds admirably, is fun to use, and will be of value to both clinical and laboratory haematologists. I thoroughly recommend it.

RJ SOKOL

Campylobacter Pylori. Ed H Menge, M Gregor, GNJ Tytgat, BJ Marshall. (Pp 249; £30.) Springer. 1988. ISBN 3540187618.

The proceedings of a symposium on a single organism sounds esoteric. This one is not. It is a collection of papers and discussions by a select group of gastroenterologists, microbiologists, histopathologists, and physiologists on the subject of gastritis and peptic ulcer disease looked at in the light of the recent discovery of Campylobacter pylori. This interdisciplinary approach gives a welcome breadth to the subject. Many of the 26 papers include informative reviews, for example, on current theories of the pathogenesis and medical management of peptic ulcer disease, and the cytoprotective action of bismuth salts. The book is well produced, with good photographic reproductions. There are a few phonetic misspellings of names mentioned in the discussions but otherwise the text seems to be accurate.

Books of this sort tend to go out of date quickly, but this one gives sufficient grounding in the subject to maintain its interest for many. Like most symposium reports it is rather expensive.

MB SKIRROW

\section{Notices}

Association of Clinical Pathologists
Junior Membership
Junior Membership of the Association of Clinical Pathologists is available to trainees
in all branches of pathology who have practised pathology for less than four years. The
annual subscription is $£ 18$ which may be claimed against tax.
All Junior Members receive monthly copies of the Journal of Clinical Pathology. Other
benefits include a regular Junior Members newsletter, the ACP newsletter, and all the
documents regularly sent to full members of the Association. These include the twice
yearly summary of pathology courses included in the ACP Postgraduate Education
Programme.
For Junior Membership apply to: Dr WR Timperley, Secretary, Association of
Clinical Pathologists, 57 Lower Belgrave Street, London SW1W 0LR.

\section{An International Update in Dermatology and Dermatopathology 2-5 September 1989}

This international meeting, jointly organised by the Pathological Society of Gt Britain and Ireland and the British Society for Dermatology, will be held at The Dome, Brighton. Lectures and seminars will be given by a panel of invited experts. Slide seminars will be presented by Dr Richard Reed, New Orleans, and Professor AB Ackerman, New York. Abstracts are invited for poster and oral presentations. A full social programme is included.

The fee is $£ 195.00$ (registration before 9 June 1989) and $£ 225.00$ after that date. Further details from: Mrs L Barducci, British Association of Dermatologists, 6 St Andrew's Place, Regent's Park, London, NW1 4LB (tel 01935 8576).

\section{Haematological Disorders Associated with Occupational Hazards}

The Health and Safety Executive, in association with the British Society for Haematology, has established a databank of blood disorders associated with exposure to occupational hazards. Clinicians are invited to notify cases to the databank.

Forms for this purpose and further information can be obtained from Mrs J Hopkins, 7th Floor Haematology Laboratory, University of Wales College of Medicine, Heath Park, Cardiff CF4 4XN. \\ The Leeds Course in Clinical Nutrition \\ 5-8 September 1989 at the University of Leeds. \\ Further details from: Mrs H L Helme, Department of Continued Professional Education, The University, Leeds LS2 9JT.}

\section{Pathological Efiects of Radiation}

11-13 September 1989 at the Holiday Inn of Bethesda, Bethesda, Maryland For further information contact: David Busch, American Registry of Pathology, Armed Forces Institute of Pathology, Washington, DC 20306-6000.

\section{Correction}

Errors were made in the text of the paper by Brandtzaeg et al J Clin Pathol 1988;41:963-70. In the Material and methods section under the heading of Immunoblotting Experiments, the second sentence should have read: For analytical focusing, $\mathrm{Ll}$ samples $(\sim 50 \mu \mathrm{g}$ in $15 \mu \mathrm{l}$ water) were applied near the cathode of agarose gels containing $7.5 \%$ Ampholine (LKB, Sweden), $\mathrm{pH} 5$ to $\mathrm{pH} 8$. The legend to figure 2 should have contained the following: There are numerous S-100 protein positive, presumably interdigitating dendritic cells (left), but also many cells of similar appearance labelled by Mac 387 (right). He apologises for these oversights. 